Article

\title{
Enhanced Electrochemical Characteristics of the Glucose Oxidase Bioelectrode Constructed by Carboxyl-Functionalized Mesoporous Carbon
}

\author{
Chuhan Lv ${ }^{1,2,3,4,+}$, Shuangfei Li ${ }^{1,2,4, \dagger}$, Liangxu Liu ${ }^{1,2,4}$, Xingyu Zhu ${ }^{1,2,4}$ and Xuewei Yang ${ }^{1,2,4, *}$ \\ 1 Guangdong Technology Research Center for Marine Algal Bioengineering, Guangdong Key Laboratory of \\ Plant Epigenetics, College of Life Sciences and Oceanography, Shenzhen University, Shenzhen 518060, \\ China; LVCHU0510@163.com (C.L.); sfli@szu.edu.cn (S.L.); liangxuliu@icloud.com (L.L.); \\ staruny9562@163.com (X.Z.) \\ 2 Shenzhen Key Laboratory of Marine Biological Resources and Ecology Environment, Shenzhen Key \\ Laboratory of Microbial Genetic Engineering, College of Life Sciences and Oceanography, \\ Shenzhen University, Shenzhen 518055, China \\ 3 College of Chemistry and Environmental Engineering, Shenzhen University, Shenzhen 518060, China \\ 4 Longhua Innovation Institute for Biotechnology, Shenzhen University, Shenzhen 518060, China \\ * Correspondence: yangxw@szu.edu.cn \\ $\dagger$ Co-first author.
}

Received: 8 May 2020; Accepted: 11 June 2020; Published: 13 June 2020

\begin{abstract}
This research revealed the effect of carboxyl-functionalization on the mesoporous carbon (MC)-fixed glucose oxidase (GOx) for promoting the properties of bioelectrodes. It showed that the oxidation time, temperature and concentration, can significantly affect MC carboxylation. The condition of $2 \mathrm{M}$ ammonium persulfate, $50^{\circ} \mathrm{C}$ and $24 \mathrm{~h}$ was applied in the study for the successful addition of carboxyl groups to MC, analyzed by FTIR. The nitrogen adsorption isotherms, and X-ray diffraction analysis showed that the carboxylation process slightly changed the physical properties of MC and that the specific surface area and pore size were all well-maintained in MC-COOH. Electrochemical characteristics analysis showed that Nafion/GOx/MC-COOH presented better electrocatalytic activity with greater peak current intensity (1.13-fold of oxidation peak current and 4.98-fold of reduction peak current) compared to Nafion/GOx/MC. Anodic charge-transfer coefficients $(\alpha)$ of GOx/MC-COOH increased to 0.77 , implying the favored anodic reaction. Furthermore, the GOx immobilization and enzyme activity in MC-COOH increased $140.72 \%$ and $252.74 \%$, leading to the enhanced electroactive GOx surface coverage of Nafion/GOx/MC-COOH electrode (22.92\% higher, $1.29 \times 10^{-8} \mathrm{~mol} \mathrm{~cm}^{-2}$ ) than the control electrode. Results showed that carboxyl functionalization could increase the amount and activity of immobilized GOx, thereby improving the electrode properties.
\end{abstract}

Keywords: mesoporous carbon; carboxylation; glucose oxidase; glucose biosensor

\section{Introduction}

Fuel cells, which convert chemical fuels into electricity, have been considered as a renewable power source for electronic equipment. Due to the minimal risk of false-positive responses, enzymes are the most promising bio-receptors used in bio-sensors [1]. Unlike noble metal catalysts which are valuable and rare, enzymes as a biological catalyst possess renewable and abundant sources [2]. Immobilizing redox enzymes (such as glucose oxidase (GOx)) onto electrode material surfaces, has become a keen interest in biofuel cell and sensor development. Anahita Karimi et al. outlined the advantages and limitations of functionalized graphene and graphene-based nanocomposite immobilized enzymes, and proved the possibility of the development of graphene-based enzyme biofuel cells [3]. Michael 
Holzinger et al. introduced different methods for immobilizing enzymes in carbon nanotubes, summarizing the application and development of carbon nanotubes in enzyme biofuel cells [4]. JingYang et al. Immobilized horseradish peroxidase on a glassy carbon electrode to construct a biocathode [5]. The novel implantable glucose fuel cells (IGFCs) are a potential energy source that can power small electronic devices such as artificial urinary sphincters, cardiac pacemakers, and implanted biosensors [6]. Although biofuel cells (BFCs) work on behalf of a new energy source, it is still tough to apply them commercially. Compared with traditional fuel cells, the application of BFCs suffers from the drawbacks of long-term instability, insufficient power output, and low open-circuit voltage (Ecell) [7]. In particular, enzyme stability is the main reason that restricts the power output of the enzymatic fuel cells [6].

Carbon materials are generally used in electroanalytical investigations due to the low background current, relatively wide potential window, and chemical inertness. Carbon materials are also appropriate for various types of analysis [8] in both analytical and industrial electrochemistry [9]. Mesoporous materials are promising for bio-molecule loading due to the narrow pore size distribution, high specific surface area, and well-ordered pore structures [10]. Large amounts of enzyme were immobilized in nanostructured carbon materials to increase the active surface area of enzymatic bio-electrodes [11]. Nanostructured materials are valid not only for steadying the enzyme activity but also for promoting the capabilities of the nano-biocatalytic systems, such as high enzyme activity, high enzyme loading and improved electron transfer rate. Enzyme immobilization in a mesoporous material could enable further practical applications, as such extending the lifespan of enzyme reactors, increasing the potentiality for recycling the enzymes and improving the power density of biofuel cells [12].

Nano-carbon materials such as graphene $[9,13,14]$ carbon nanotubes (single-wall, multi-wall) [15-17], and mesoporous carbon [18,19] are commonly used in immobilizing enzymes and developing enzyme-based electrochemical devices. Mesoporous carbon (MC) obtains properties appropriate for application in biofuel cells and biosensors, including high specific surface areas, high specific pore volume, extremely well-ordered pore structure, tunable pore diameters in the mesopore range and conductivity [20,21]. The most interesting property is that MC can ensure the direct electronic connection of each immobilized matter, enabling electronic penetration [20]. Furthermore, MC obtains additional edge-plane-like deficient sites [22], which are more advantageous for electron transfer to $\mathrm{H}_{2} \mathrm{O}_{2}$ and $\mathrm{NADH}[23,24]$. It makes $\mathrm{MC}$ transfer electrons to biomolecules more efficiently, thus contributing to the impressive electrochemical behavior [8]. However, MC also exhibits hydrophobic properties and an unreactive surface on account of the shortage of oxygen-containing functional groups caused by the high carbonization temperature during synthesis [25]. The inferior hydrophobicity and surface reactivity of MC limit the enzyme immobilization and prohibit the access of reactants from the solution to the effective sites of the enzymes on the electrode surface [26].

To further activate the surface of MC and overcome the deficiencies mentioned above, a number of methods that apply strong oxidation agents (nitric acid, ozone, and sulfuric acid) to generate some oxygenated functionalities have been explored. It is known that functional nanomaterials can cause a synergistic effect among biocompatibility, conductivity, and catalytic activity to speed up signal transduction, leading to highly sensitive biosensing [27]. For example, Y. Shin et al. used sulfur-functionalized mesoporous carbon as a heavy-metal sorbent [28]. Guide Yang et al. used nitrogen-functionalized magnetic $\mathrm{MC}$ as a sorbent to adsorb $\mathrm{Pb}$ (II) and phenol [29]. Ajayan Vinu et al. discussed the effect of different carboxylation conditions on the adsorption and fixation of lysozyme by mesoporous carbon [30]. However, there are few reports on the use of carboxyl-functionalized MC to enhance enzyme activity and electrochemical properties of its related electrodes. 
To explore the carboxylic functionalization conditions for $\mathrm{MC}$, oxidation temperature, oxidant concentration, and oxidation time were studied. The functional groups, skeleton structure, pore volume and specific surface area of MC after carboxyl functionalization (MC-COOH) were investigated by Fourier transform infrared (FTIR) spectrometer, wide-angle X-ray diffraction (XRD) diffractometer, and nitrogen adsorption specific surface area analyzer (BET). The influence of-COOH group on the amount and enzyme activity of immobilized GOx was analyzed. Finally, the electrode was prepared using $5 \%$ Nafion solution, and the electrochemical properties were analyzed by cyclic voltammetry $(\mathrm{CV})$.

\section{Materials and Methods}

\subsection{Carboxyl Functionalization}

MC (pore volume of $0.5 \mathrm{~cm}^{3} \mathrm{~g}^{-1}$, surface area of 150-250 $\mathrm{m}^{2} \mathrm{~g}^{-1}, 699640$, Sigma-Aldrich Corp. St. Louis, MO, USA) was oxidized using an alike process to that reported in the literature [31,32] via oxidation using solutions of ammonium persulfate $\left(\left(\mathrm{NH}_{4}\right)_{2} \mathrm{~S}_{2} \mathrm{O}_{8}\right.$, APS) with different concentrations ranging from 0 to $2 \mathrm{M}$ in $2 \mathrm{M}$ sulfuric acid $\left(\mathrm{H}_{2} \mathrm{SO}_{4}\right)$. In a conventional oxidation experiment, $300 \mathrm{mg}$ of MC was added to $20 \mathrm{~mL}$ of the APS solution. To utilize DF-101S heat-collecting magnetic stirrer (Qiuzuo Scientific Instrument Co., Ltd., Shanghai, China), the mixture was stirred at $30 \mathrm{rpm}$ for diverse periods of time up to a maximum of $96 \mathrm{~h}$ and at various temperatures ranging from 30 to $80^{\circ} \mathrm{C}$. All the oxidized samples were filtered, washed a few times with distilled water until the washing water was without sulfates, and dried overnight in vacuum drying oven (DZF-6050, Shanghai Yiheng Scientific Instruments Co., Ltd., Shanghai, China).

\subsection{GOx Immobilization on $\mathrm{MC}-\mathrm{COOH}$}

The immobilization experiment was conducted by suspending $20 \mathrm{mg}$ of $\mathrm{MC}-\mathrm{COOH}$ and $\mathrm{MC}$ in $1 \mathrm{~mL} 0.05 \mathrm{M}$ pH 7.0 PBS buffer, which contains $10 \mathrm{mg} \mathrm{m}^{-1}$ GOx (246 U mg ${ }^{-1}$, G8032, Beijing Solarbio Science \& Technology Co., Ltd., Beijing, China) at room temperature in a centrifuge tube. The consequent intermixture of GOx solution and the supports was then incubated at $10{ }^{\circ} \mathrm{C}$ with agitating at 220 rpm (LYZ-D2403 Superimposed Shaker, Shanghai Longyue Instrument Equipment Co., Ltd., Shanghai, China) for $6 \mathrm{~h}$ to attain adsorption equilibrium [30]. After immobilization, the samples were centrifuged (75008800 Medifuge Centrifuge, Thermo Fisher Scientific Co., Ltd., San Jose, CA, USA) at 10,000 rpm for $5 \mathrm{~min}$. The free GOx particles were subsequently separated, and the solid part (GOx/COOH-MC) was washed with PBS buffer 3 times, dried under vacuum using a lyophilizer (triad 2.51, LABCONCO, USA) and stored at $-20{ }^{\circ} \mathrm{C}$ for further use. In each set of experiments, three biological replicates were performed.

The amount of GOx immobilized on $\mathrm{MC}$ and $\mathrm{MC}-\mathrm{COOH}$ particles was computed by ascertaining the original and terminal concentration of GOx in the liquid solution through ultraviolet spectrophotometry at $450 \mathrm{~nm}$ (EPOCH 2 microplate reader, Bio Tek, Winooski, VT, USA). The glucose oxidase activity of GOx/MC-COOH and GOx/MC was analyzed by utilizing a glucose oxidase assay Kit (BC0695, Beijing Solarbio Science \& Technology Co., Ltd., Beijing, China). In each set of experiments, three biological replicates were performed.

\subsection{Fabrication of GOx/MC and GOx/MC-COOH Bioelectrodes}

The glucose bioelectrode was made through pipetting $20 \mathrm{mg}$ of the dispersions of GOx/MC and GOx/MC-COOH in a pH 7.0 PBS buffer solution with $0.5 \%$ Nafion onto carbon cloth as an anode [33]. After drying the Nafion/GOx/MC and Nafion/GOx/MC-COOH-coated carbon cloth electrodes in the air at room temperature, they were rinsed meticulously with pH 7.0 PBS buffer, and stored at $4{ }^{\circ} \mathrm{C}$ before use. The experimental scheme was shown as Figure 1. 


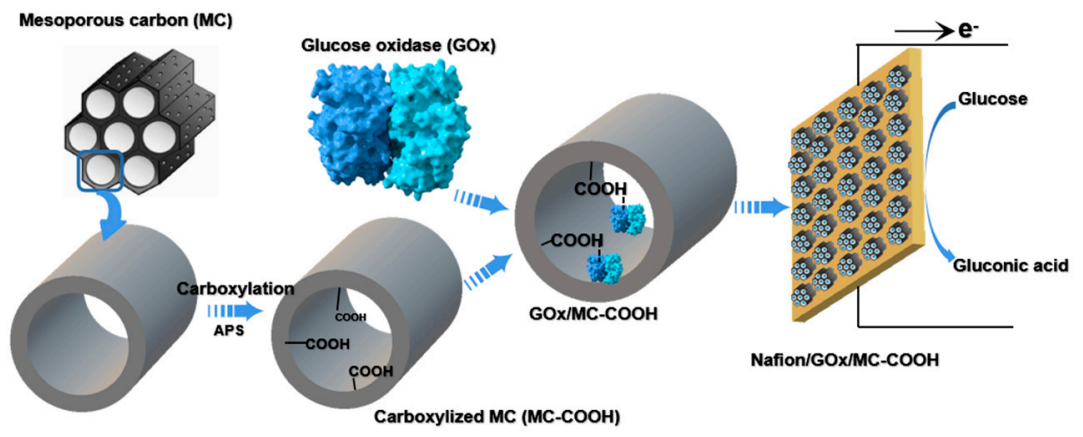

Figure 1. Experimental scheme of mesoporous carbon (MC)-COOH preparation and enzyme immobilization.

\subsection{Characterization of $\mathrm{MC}-\mathrm{COOH}$}

FTIR spectra of the samples in the $400-4000 \mathrm{~cm}^{-1}$ region were acquired on a Nicolet 6700 (USA) spectrometer using the usual $\mathrm{KBr}$ pellet technique. XRD analyses were performed on an Empyrean diffractometer (PANalytical B.V., Almelo, The Netherlands) using copper anode radiation over the range of $10^{\circ}-80^{\circ}$. Nitrogen sorption isotherms were measured with an ASPS 2460 (Micromeritics Instruments Corporation, Norcross, GA, USA) analyzer at 77.4 K. In front of measurement, the powders were degassed at $80^{\circ} \mathrm{C}$ under vacuum for more than $6 \mathrm{~h}$.

\subsection{Electrochemical Measurements of Glucose Bioelectrodes}

By using an Autolab PGSTAT $302 \mathrm{~N}$ (Switzerland) potentiostat, all electrochemical processes were analyzed. CV was performed in a three-electrode system, which contains a platinum piece counter electrode, an $\mathrm{Ag} / \mathrm{AgCl}$ electrode, and a working electrode. $\mathrm{CV}$ scans were performed at $20-200 \mathrm{mV} \cdot \mathrm{s}^{-1}$ scan in the potential range from -1.0 to $1.0 \mathrm{~V}(\mathrm{v} . \mathrm{s} . \mathrm{Ag} / \mathrm{AgCl}$ ) in air-saturated $0.1 \mathrm{M} \mathrm{pH}$ 7.0 PBS supplemented with $10 \mathrm{mM}$ glucose at room temperature.

\section{Results}

\subsection{Effect of Carboxylation Conditions on GOx Adsorption}

To investigate the influence of carboxylation conditions on GOx immobilization on $\mathrm{MC}-\mathrm{COOH}$, various reaction conditions, including different oxidation temperatures, APS concentrations, and reaction times, were investigated, shown as Figure 2. The results showed that the carboxylation condition could significantly influence the GOx immobilization in MC-COOH. Compared with MC, MC-COOH exhibited obvious advantages in enzyme adsorption capacity.

\subsubsection{Temperature}

As shown in Figure 2a, the carboxylation temperature $\left(30\right.$ to $\left.80^{\circ} \mathrm{C}\right)$ could greatly influence the GOx adsorption (increasing from $23.60 \%$ to $89.13 \%$ ) in $\mathrm{MC}-\mathrm{COOH}$. As the temperature increased from 30 to $60^{\circ} \mathrm{C}$, the GOx adsorption raised from 2.09 to $3.19 \mathrm{mg}$ GOx/20 mg MC. The GOx absorption of MC-COOH (3.19 mg GOx/20 mg MC) carboxylated at $60{ }^{\circ} \mathrm{C}$ increased by $89.13 \%$ compared with the unmodified MC (1.69 mg GOx/20 mg MC). However, as the temperature increased from 60 to $80{ }^{\circ} \mathrm{C}$, a decrease in the GOx adsorption (from 3.19 to $2.90 \mathrm{mg} \mathrm{GOx} / 20 \mathrm{mg} \mathrm{MC}$ ) in MC-COOH was observed. Previous research showed that the oxidation temperature affected the concentration of oxygen-containing groups (acid anhydrides, strongly acidic carboxyl groups, phenols, carbonyls, weakly acidic carboxyl groups, quinones, and lactones) on the surface of the carbon material [34]. It was known that lower temperature profited the alternative formation of acidic MC (containing carboxyl, lactone, lactol, anhydride and phenol) while using APS as the oxidizing agent, whereas higher temperature favored the selective formation of alkalescent MC (containing carbonyl, pyrone, ether and 
quinone) [35]. Oxidation of mesoporous carbon at lower temperatures will cause oxygen-containing groups to block the pores of the carbon. As the temperature increases, the blocked pores will open, and the specific surface area and total pore volume will be higher than that of carbon materials oxidized at low temperature. Relatively high temperature will cause the total pore volume and specific surface area of the material to be greatly reduced, which is not conducive to adsorption of enzymes [36]. In Figure 2a, it can be seen that the adsorption of mesoporous carbon oxidized at $50{ }^{\circ} \mathrm{C}$ and $60{ }^{\circ} \mathrm{C}$ were higher. Thus the appropriate temperature was important that it should be high enough to increase the concentration of weakly acidic carboxyl groups, as well as low enough to form the acidic MC [35], which was more favorable to covalent adsorption.

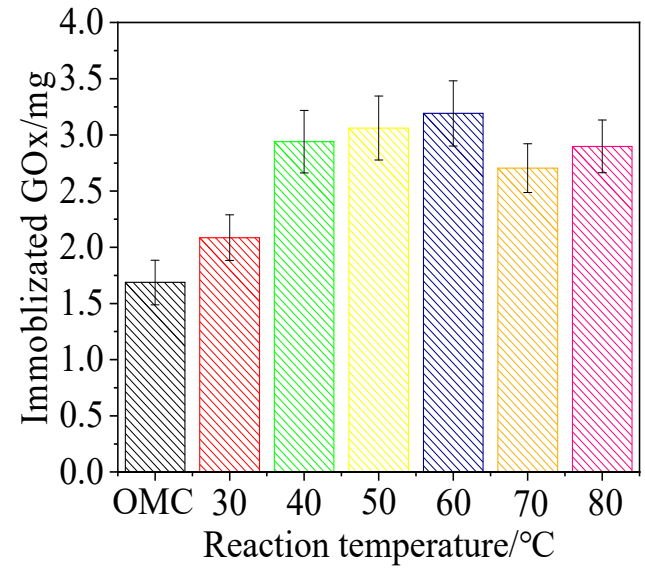

(a)

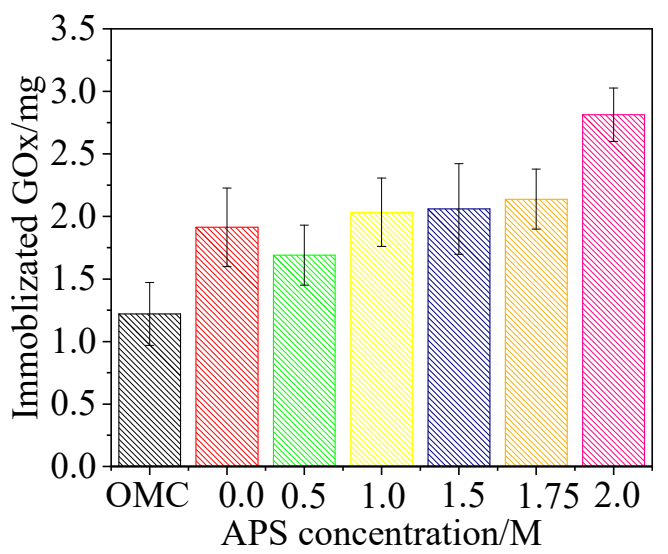

(b)

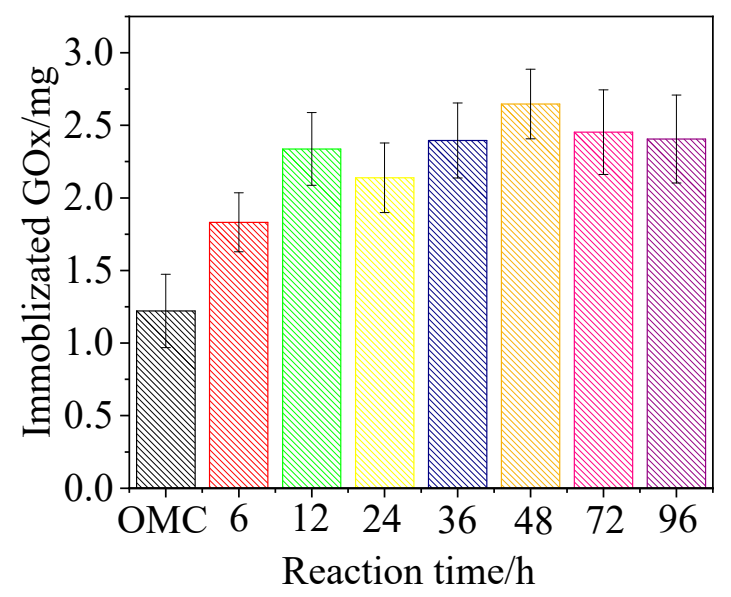

(c)

Figure 2. Effects of the carboxylation conditions on the glucose oxidase (GOx) immobilization in carboxylated mesoporous carbon; (a) $1.75 \mathrm{M}$ ammonium persulfate (APS), $2 \mathrm{M} \mathrm{H}_{2} \mathrm{SO}_{4}$ at different temperature $\left(30,40,50,60,70,80{ }^{\circ} \mathrm{C}\right)$ for $24 \mathrm{~h}$; (b) 0, 0.5, 1.0, 1.5, 1.75, $2.0 \mathrm{M} \mathrm{APS}, 2 \mathrm{M} \mathrm{H}_{2} \mathrm{SO}_{4}$ at $50{ }^{\circ} \mathrm{C}$ for $24 \mathrm{~h}$; (c) $1.75 \mathrm{M}$ APS and $2 \mathrm{M} \mathrm{H}_{2} \mathrm{SO}_{4}$ at $50{ }^{\circ} \mathrm{C}$ for $6,12,24,36,48,72,96 \mathrm{~h}$.

\subsubsection{APS Concentration}

The amounts of immobilized GOx in MC-COOH with various APS concentrations were presented in Figure 2B. Without adding APS, the GOx adsorption of MC stands at $2.09 \mathrm{mg}$ GOx/20 mg MC. Then, the GOx adsorption rose marginally from $0 \mathrm{M}$ to $1.75 \mathrm{M}(2.14 \mathrm{mg} \mathrm{GOx} / 20 \mathrm{mg} \mathrm{MC})$. After that, it rose 
rapidly, reaching $2.81 \mathrm{mg} \mathrm{GOx} / 20 \mathrm{mg} \mathrm{MC}$ at $2 \mathrm{M}$. Compared with the MC, the sample carboxylated at an APS concentration of $2 \mathrm{M}$ adsorbed $130.47 \%$ more GOx. Oxidation with APS was conducive to enhance the concentration of acidic oxygen groups (carboxyl, anhydride and phenol groups). However, oxidation with APS solutions also led to diverse degrees of reduction in pore volume and surface area on the basis of the APS concentration. The porous carbon structure using a higher concentration of APS would be destroyed or collapsed [35], which greatly affected the fixation of GOx. Thus the APS concentration $(2 \mathrm{M})$ was significant to form target chemical groups without excessively destroying the specific surface area and pore size of MC.

\subsubsection{Time}

Moreover, Figure 2C presented the effects of the MC carboxylation reaction time ( $6 \mathrm{~h}$ to $96 \mathrm{~h}$ ) on GOx immobilization, which showed the GOx absorption of $48 \mathrm{~h} \mathrm{(2.65} \mathrm{mg} \mathrm{GOx/20} \mathrm{mg} \mathrm{MC)} \mathrm{and}$ $72 \mathrm{~h}(2.45 \mathrm{mg} \mathrm{GOx} / 20 \mathrm{mg} \mathrm{MC})$ were largest. In particular, compared to the unmodified MC, the MC samples carboxylated for $48 \mathrm{~h}$ and $72 \mathrm{~h}$ exhibited 2.17 times and 2.01 times more immobilized enzyme,

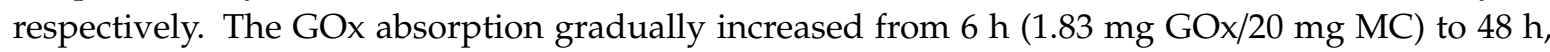
then declined by $15.88 \%-3.86 \%$ compared to $48 \mathrm{~h}$. During the oxidization process, the concentration of surface lactone groups rose smoothly with time, which was similar to the concentration of carboxyl groups. However, the differences between samples of the concentration of surface lactone groups subjected to different treatment times sharply increased, which meant that the amount grew both by oxidation of the surface phenol groups and by direct formation of lactones. The number of lactone groups changed in correlation with the reaction time, which affected the degree of oxidation of the material [37]. Analyzed by the statistical analysis, MC with $48 \mathrm{~h}$ oxidation had significant differences among each group in terms of GOx absorption. Thus the reaction time (48 h) was suitable for the preferable oxidation of MC.

Above all, the results showed that the oxidation temperature, APS concentration, and reaction time could significantly influence MC carboxylation and consequently improve GOx immobilization. From the above experiments, it was found that the adsorption capacity of GOx increased the most (compared with MC, an increase of $130.47 \%$ ) under $2 \mathrm{M}$ APS, $50{ }^{\circ} \mathrm{C}$ and $24 \mathrm{~h}$ carboxylation conditions. Thus, the MC oxidized by this condition was selected in the subsequent experiments to prepare electrodes.

\subsection{Characterization of $\mathrm{MC}-\mathrm{COOH}$}

\subsubsection{Fourier Transform Infrared (FTIR) Spectrum Analysis}

According to the FTIR analysis results, three bands centered at approximately $3451.50 \mathrm{~cm}^{-1}$, $1638.64 \mathrm{~cm}^{-1}$, and $1523.94 \mathrm{~cm}^{-1}$ (Figure 3a, A) were clearly visible in the MC-COOH spectrum, which was not observed in the MC spectrum. The absorption band at $1638.64 \mathrm{~cm}^{-1}$ belonged to the stretching frequency of $\mathrm{C}=\mathrm{O}$ in carboxylic group $(\mathrm{O}=\mathrm{C}-\mathrm{OH})[38,39]$. The band at $1523.94 \mathrm{~cm}^{-1}$ could be attributed to the symmetric COO- oscillation and/or aromatic ring stretching coupled with greatly conjugated keto groups [31]. The broad peak at $3451.50 \mathrm{~cm}^{-1}$ was ascribed to the $-\mathrm{OH}$ oscillation $[39,40]$. The bands at $1256.22 \mathrm{~cm}^{-1}$ were observed in both MC-COOH and MC, attributed to C-O-C asymmetric oscillations in ether groups of oxidized mesoporous carbon, which were observed in both MC-COOH and MC [41,42]. These results clearly indicated that $-\mathrm{COOH}$ groups were formed on the carbon frameworks by the oxidative treatment. 


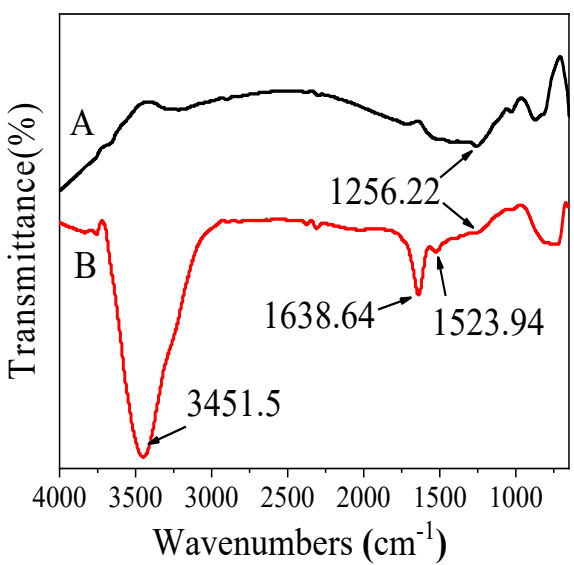

(a)

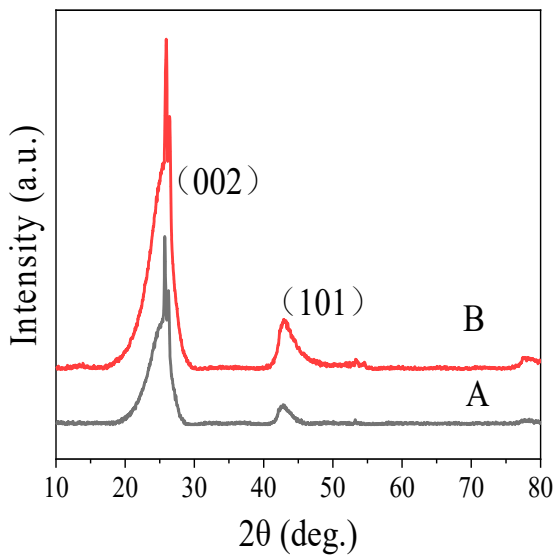

(b)

Figure 3. Fourier transform infrared (FT-IR) spectra (a) and X-ray diffraction patterns (XRD) (b) of MC (A) and $\mathrm{MC}-\mathrm{COOH}(\mathrm{B})$.

\subsubsection{Wide-Angle X-ray Diffraction (XRD) Analysis}

In the wide-angle XRD patterns (Figure 3b), the MC and MC-COOH nanocomposites displayed two extremely sharp peaks centered at approximately $26^{\circ}$ and $43^{\circ}$, which corresponded to the (002) and (101) diffractions of graphite [43,44]. The weak diffraction peak around $12.8^{\circ}$ (Figure 3b, B) would indicate the presence of graphite oxide $[45,46]$. It was inferred that the graphitic character of the samples might derive from the highly carbonized MC framework or from the carboxylation reaction [47]. Moreover, the XRD pattern of $\mathrm{MC}-\mathrm{COOH}$ was similar to that of $\mathrm{MC}$, indicating that there was barely damage to the structure and composition of MC-COOH [32]. Above all, the FTIR and XRD analysis revealed that after functionalization, carboxyl groups were successfully added to MC with a slight change in the skeleton structure.

\subsubsection{Nitrogen Adsorption Specific Surface Area (BET) Analysis}

Nitrogen adsorption/desorption isotherms, and the corresponding pore size distribution curves of the MC and MC-COOH samples were presented in Figure 4. It revealed that the obtained isotherms of two samples (shown as Figure 4a) could rank as type IV isotherms, which exhibited $\mathrm{H}_{4}$ hysteresis loops and an obvious capillary condensation step $[31,48]$. Various isotherms showed distinct hysteresis loops, presenting the characteristics of a porous adsorbent [49]. Type $\mathrm{H}_{4}$ hysteresis loops, often did not close before approaching the saturation pressure, were also structured by slit-shaped pores, reflecting the characteristics of activated carbon materials [50]. The hysteresis loop of MC-COOH was situated at $\mathrm{P} / \mathrm{P}_{0}$ values between 0.6 and 0.8 , bespeaking that $\mathrm{MC}-\mathrm{COOH}$ had an abundant uniform mesoporous structure [40,51].

In addition, the pore size distribution curve based on the adsorption data explicitly identified a limited pore size distribution within 4-12 nm (Figure $4 \mathrm{~b}$ ) and showed that the peak pore sizes of MC (a) and $\mathrm{MC}-\mathrm{COOH}(\mathrm{b})$ were centered at $6.23 \mathrm{~nm}$, and $6.70 \mathrm{~nm}$, respectively, which allowed them to suitably fix GOx since the threshold pore aperture value to immobilize GOx on nanoporous materials was $3.50 \mathrm{~nm}$ [52]. The pore structure parameters of $\mathrm{MC}$ and $\mathrm{MC}-\mathrm{COOH}$ were based on the BET equation to the $\mathrm{N}_{2}$ adsorption isotherm at $77 \mathrm{~K}$, as shown in Table 1. Pore size distribution was a significant property with regard to porous adsorbents. The average adsorption pore widths (4 V/SBET) of MC and $\mathrm{MC}-\mathrm{COOH}$ were acquired to be $7.99 \mathrm{~nm}$ and $9.24 \mathrm{~nm}$, separately. Moreover, no significant differences in mesopore volume and total pore volume between $\mathrm{MC}$ and $\mathrm{MC}-\mathrm{COOH}$ were found, indicating that after functionalization, $\mathrm{MC}-\mathrm{COOH}$ successfully maintained the mesoporous structure. In conclusion, MC-COOH exhibited the appropriate pore size and pore volume for the GOx immobilization. 


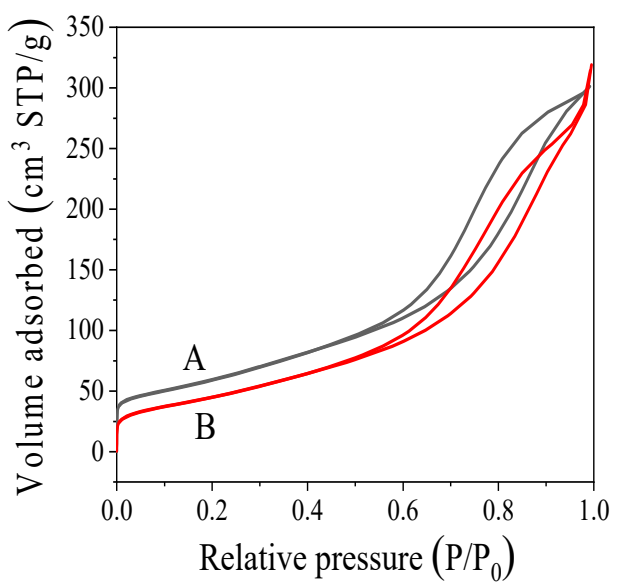

(a)

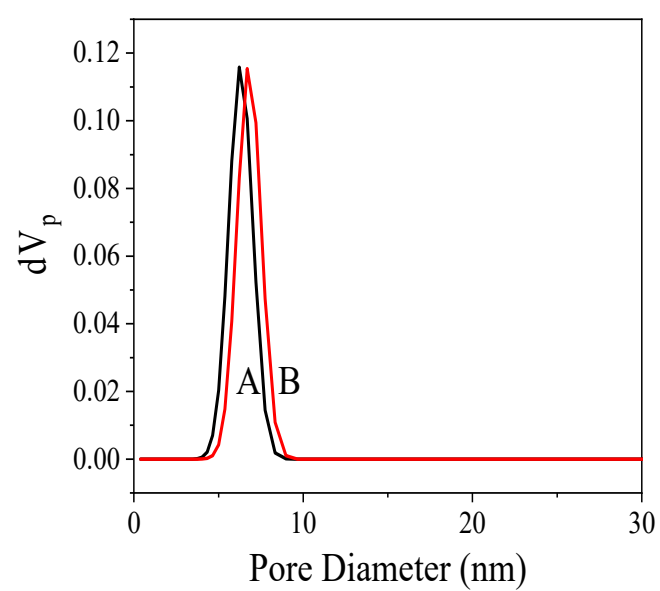

(b)

Figure 4. Nitrogen adsorption-desorption isotherms (a) and pore size distribution (b) of MC (A) and $\mathrm{MC}-\mathrm{COOH}(\mathrm{B})$.

Table 1. Pore structure parameters of $\mathrm{MC}$ and $\mathrm{MC}-\mathrm{COOH}$.

\begin{tabular}{cccccc}
\hline & $\mathbf{S}_{\text {BET }}\left(\mathbf{m}^{\mathbf{2}} \mathbf{g}^{-\mathbf{1}}\right)$ & $\mathbf{V}\left(\mathbf{c m}^{\mathbf{3}} \mathbf{g}^{-\mathbf{1}}\right)$ & $\mathbf{W}_{\text {BJH }}(\mathbf{n m})$ & $\left.\mathbf{W}_{\mathbf{d}} \mathbf{( n m}\right)$ & $\mathbf{S}_{\text {BJH }}\left(\mathbf{m}^{\mathbf{2}} \mathbf{g}^{-\mathbf{1}}\right)$ \\
\hline MC & 226 & 0.4515 & 4.42 & 7.99 & 202.79 \\
$\mathrm{MC-COOH}$ & 181 & 0.4184 & 4.42 & 9.24 & 181.55 \\
\hline
\end{tabular}

$\mathrm{S}_{\mathrm{BET}}$ represents the BET surface area $\left(\mathrm{S}_{\mathrm{BET}}\right)$, the $\mathrm{BJH}$ surface area $\left(\mathrm{S}_{\mathrm{BJH}}\right)$, single point adsorption total pore volume $(\mathrm{V})$, the $\mathrm{BJH}$ volume $\left(\mathrm{V}_{\mathrm{BJH}}\right)$, the $\mathrm{BJH}$ pore diameter $\left(\mathrm{W}_{\mathrm{BJH}}\right)$ and adsorption average pore width $\left(\mathrm{W}_{\mathrm{d}}\right)(4 \mathrm{~V} / \mathrm{SBET})$.

\subsection{Direct Electrochemistry of Bioelectrodes Nafion/GOx/MC and Nafion/GOx/MC-COOH}

$\mathrm{CV}$ scans of Nafion/MC, Nafion/MC-COOH, Nafion/GOx/MC and Nafion/GOx/MC-COOH were obtained, as shown in Figure 5. In the absence and presence of glucose shown as Figure 5A-C, there is no obvious peak corresponding to the glucose oxidation in the electrode Nafion/MC $(\mathrm{a}, \mathrm{e})$ and Nafion/COOH-MC $(b, h)$, indicating that there is no biochemical reaction on the bare $\mathrm{MC}$ or $\mathrm{COOH}-\mathrm{MC}$ to produce electrons [53]. Thus, the currents observed in bioelectrode MC-GOx and COOH-MC-GOx were mainly contributed by the GOx catalysis. As Figure 5A, c, d showed, the oxidation peak current of COOH-MC-GOx was much higher (1.13 times) than MC-GOx. It was known that the direct electron-transfer behavior of the GOx-electrode is as the following [54-56]:

$$
\mathrm{GOx}(\mathrm{FAD})+\text { Glucose } \rightarrow \text { gluconolactone }+\mathrm{GOx}\left(\mathrm{FADH}_{2}\right)
$$

As is well known, glucose is the substrate of GOx, whose presence will result in an oxidation reaction and increase the oxidative peak current on electrode surface. Previous studies presented that the redox peak current signal shows the increase due to the electron transfer that occurs between the active sites of glucose oxidase and electrodes [57]. Thus, the GOx content is critical in glucose oxidation. In Table 2, results showed that the amount and enzyme activity of GOx immobilization in the COOH-MC was higher than that of MC-GOx. The total amount of GOx immobilized in $\mathrm{COOH}-\mathrm{MC}$ was 1.34 times more than that in MC. The increase of the oxidation peak current $(280 \mu \mathrm{A})$ in $\mathrm{COOH}-\mathrm{MC}$ is possibly due to the increase of GOx immobilization, thus enhancing the bioactivity of immobilized COOH-MC-GOx. 


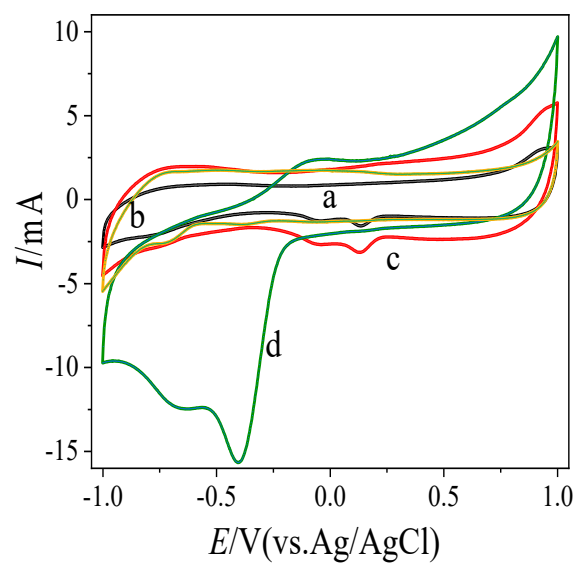

(A)

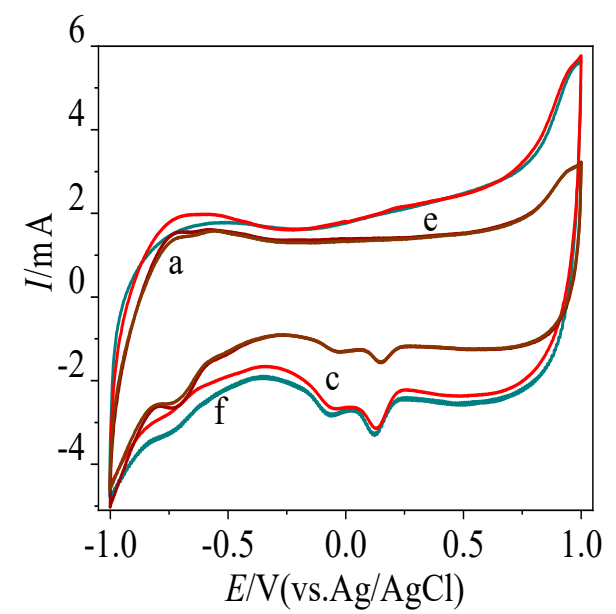

(B)

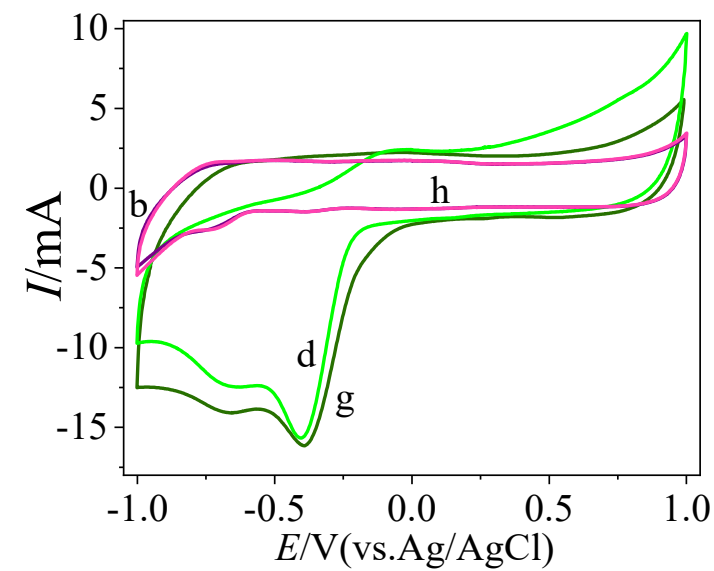

(C)

Figure 5. (A) Cyclic voltammetry (CV) of MC (a), MC-COOH (b), MC-GOx (c) and COOH-MC-GOx (d) in air-saturated PBS $0.1 \mathrm{M} \mathrm{pH} 7.0$ at scan rate of $50 \mathrm{mV} \mathrm{s}^{-1}$ with the addition of $10 \mathrm{mM}$ glucose; (B) CV of MC with (a) and without glucose (e), MC-GOx with (c) and without glucose (f) in air-saturated PBS $0.1 \mathrm{M} \mathrm{pH} 7.0$ at scan rate of $50 \mathrm{mV} \mathrm{s}^{-1}$; (C) CV of COOH-MC with (b) and without glucose (h), COOH-MC-GOx with (d) and without glucose (g) in air-saturated PBS $0.1 \mathrm{M} \mathrm{pH} 7.0$ at scan rate of $50 \mathrm{mV} \mathrm{s}^{-1}$.

Table 2. Enzyme activity of glucose oxidase immobilized in MC and COOH-MC.

\begin{tabular}{cccc}
\hline Carbon Type & $\begin{array}{c}\text { Quality of Immobilized } \\
\text { Enzyme } \\
\text { (GOx mg/MC g) }\end{array}$ & $\begin{array}{c}\text { Immobilized Enzyme } \\
\text { Activity } \\
\text { (U/g) }\end{array}$ & $\begin{array}{c}\text { Unit Enzyme Activity } \\
\text { U/mg }\end{array}$ \\
\hline GOx/MC & 61.06 & 16220.60 & 265.64 \\
GOx/MC-COOH & 140.72 & 57216.50 & 406.60 \\
\hline
\end{tabular}

There were two cathodic peaks observed in the CV curve of the bio-electrode constructed with Nafion/GOx/MC-COOH. In the presence of oxygen, the reduced enzyme is oxidized very quickly at the surface of the electrode $[55,56,58]$ :

$$
\text { GOx-FADH }{ }_{2}+\mathrm{O}_{2} \rightarrow \mathrm{GOx}-\mathrm{FAD}+\mathrm{H}_{2} \mathrm{O}_{2}
$$

The catalytic regeneration of the enzyme in its oxidized form causes the loss of reversibility and the increase in size of the reduction peak [58-60]. In the air-saturated buffer solution, the shape of CV curve for the direct electron-transfer of GOx showed an increase of reduction peak current, 
indicating that GOx in the MC and COOH-MC catalyzed the oxygen reduction. Since the main reductive reaction was due to the $\mathrm{O}_{2}$ reduction by GOx, the maximum cathodic peak at $-0.430 \mathrm{~V}$ was speculated to be the peak of reducing oxygen. The similar phenomenon were also observed in other bio-electrodes constructed with GOx as the catalyst. Two peaks appeared in the CV curves of GOD-graphene/PANI/AuNPs modified GCE in an $\mathrm{N}_{2}$-saturated PBS [61]. The graphene/polyaniline/Au nanoparticles/glucose oxidase biocomposite modified screen-printed electrode in air-saturated PBS with different glucose concentrations also showed two cathodic peaks [54]. It was reported that the electrode of Nafion-Graphene-GOD/GE exhibited two cathodic peaks in the CV chart under air saturated PBS with different glucose concentrations [56]. Moreover, the electrode constructed by GOx-GMC nanocomposite with $0.13 \%$ of GA showed two cathodic peaks in the CV graph scanned under $\mathrm{N}_{2}$ saturated PBS [62]. In Figure 5, the CV responses of MPC-CHT-GOx/SPCE and MWCNT-CHT-GOx showed two cathodic peaks in the absence and presence of $3 \mathrm{mM}$ glucose containing $\mathrm{O}_{2}$ saturated 0.1 M PBS [63]. However, the reason for the second cathodic peak still stays unclarified. A possible explanation might be that the reduction of the glucose oxidase itself could produce a relatively weak cathodic peak [54-56,58,59,64].

To further study the properties of Nafion/GOx/MC (Figure 6A) and Nafion/GOx/MC-COOH (Figure 6B) in the presence of glucose, $\mathrm{CV}$ scanning was performed in air-saturated PBS with $10 \mathrm{mM}$ $\mathrm{C}_{6} \mathrm{H}_{12} \mathrm{O}_{6}$ with different scan rates. We found that peak potential shifted toward more positive while in reverse toward more negative as the scan rate increased. This phenomenon was typical for irreversible and quasi-reversible systems [65], indicating facile electron transfer kinetics [66]. The good linear relationship between the peak currents versus scan rates [67] (Figure 6, inset $A_{1}, B_{1}$ ) showed that the electron transfer was a surface-controlled electrochemical process [68-70] related to the electrode's electroactive GOx surface coverage $(\Gamma)$ [71]. It revealed that charge transport was not controlled by diffusion [58], because the dependence of peak currents vs. scan rate barely deviated from linearity [66]. According to [72-74], the inter-facial electron transfer on the Nafion/GOx/MC and Nafion/GOx/MC-COOH electrodes were calculated by means of the method of Laviron [75]. Since the $\Delta \mathrm{E}_{\mathrm{P}}$ in the voltammetric curve (Figure 6A) was less than or more than $100 \mathrm{mV}(200 / n$, where $n$ is the number of electrons transferred), the $\mathrm{E}_{\mathrm{pc}}$ and $\mathrm{E}_{\mathrm{pa}}$ linearized in accordance with the logarithm of the scan rates $(\mathrm{v})$, which slopes were $-2.3 \mathrm{RT} / \mathrm{anF}$ and $2.3 \mathrm{RT} /(1-\mathrm{a}) \mathrm{nF}$, respectively (Figure $6 \mathrm{~A}$, inset $\mathrm{A}_{2}$, and Figure $6 \mathrm{~B}$, inset $\left.\mathrm{B}_{2}\right)$. Hence, the anodic charge-transfer coefficients $(\alpha)$ of Nafion/GOx/MC and Nafion/GOx/MC-COOH were calculated to be 0.67 and 0.77 . The $\alpha$ increased as the amount of fixed GOx increased, starting with $\alpha=0.67$ (GOx concentration was $1.22 \mathrm{mg}$ GOx/20 $\mathrm{mg} \mathrm{MC}$ ) up to approximately $\alpha=0.77$ (GOx concentration was $2.81 \mathrm{mg} \mathrm{GOx} / 20 \mathrm{mg} \mathrm{MC}$ ) [76]. This finding implied that the anodic reaction (glucose oxidation by GOx) was favored.

Additionally, the activity of the GOx immobilized on MC and MC-COOH was investigated (Table 2). The activity of GOx/MC-COOH was $57,216.50 \mathrm{U} \mathrm{g}^{-1}$, which was $252.74 \%$ higher than the GOx/MC activity. The GOx immobilized on MC-COOH had a unit enzyme activity of $406.60 \mathrm{U} \mathrm{mg}^{-1}$, which was 1.65 times greater than the unit enzyme activity of free GOx. The GOx immobilized on MC-COOH exhibited maximal activity. The total charge (Q) of the electrode was calculated from the integration of the $\mathrm{CV}$ peaks for estimating the electrical activity of the reductase or oxidase. The surface coverages $(\Gamma)$ of electroactive GOx in Nafion/GOx/MC and Nafion/GOx/MC-COOH were $1.05 \times 10^{-8}$ mol cm${ }^{-2}$ and $1.29 \times 10^{-8} \mathrm{~mol} \mathrm{~cm}^{-2}$, respectively. The value was calculated according to $\Gamma=Q / \mathrm{nFA}$, where $\mathrm{Q}$ is the charge obtained from the integrals of the anodic peak, $n$ is the number of electrons transferred, F is the Faraday constant, and A is the electrode area $\left(2.25 \mathrm{~cm}^{2}\right)$ [77]. This value was far more than that of monolayer GOx covering the surface of the bare electrode $\left(2.86 \times 10^{-12} \mathrm{~mol}\right.$ $\mathrm{cm}^{-2}$ ) [78], which showed that multilayer and three-dimensional GOx coverage were formed on MC and $\mathrm{MC}-\mathrm{COOH}$. 


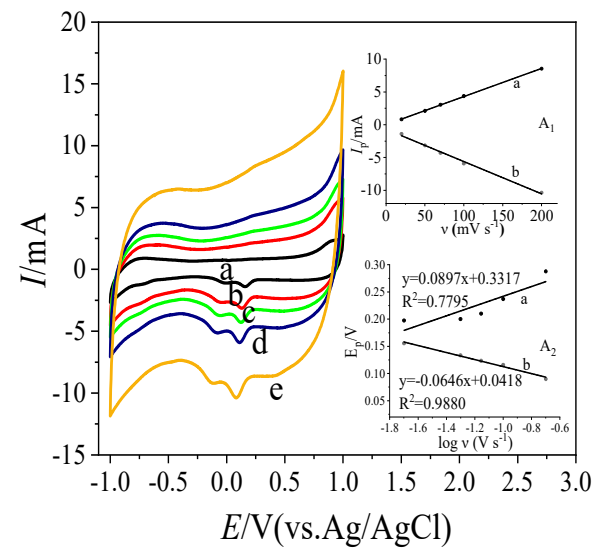

(A)

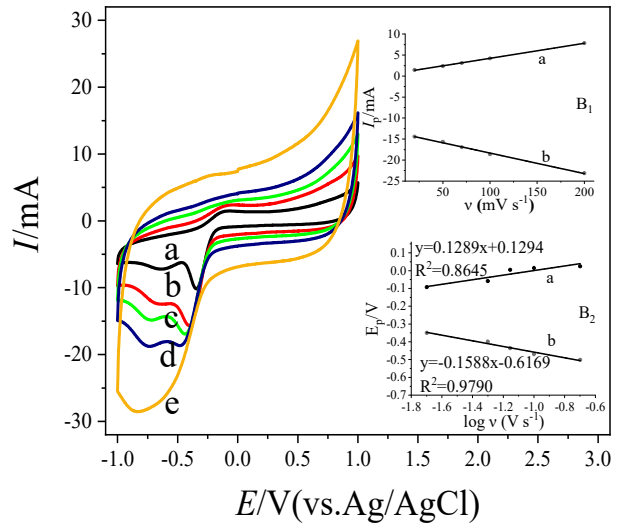

(B)

Figure 6. (A) $\mathrm{CV}$ of MC-GOx at different scan rates $\left(20 \mathrm{mV} \mathrm{s}^{-1}\right.$ (a), $50 \mathrm{mV} \mathrm{s}^{-1}$ (b), $70 \mathrm{mV} \mathrm{s}^{-1}$ (c), $\left.100 \mathrm{mV} \mathrm{s}^{-1}(\mathrm{~d}), 200 \mathrm{mV} \mathrm{s}^{-1}(\mathrm{e})\right)$, insets $\left(\mathrm{A}_{1}\right.$ and $\left.\mathrm{A}_{2}\right)$ are plots of anodic and cathodic peak currents vs. scan rate and peak potentials vs. log scan rates respectively. (B) $\mathrm{CV}$ of $\mathrm{COOH}-\mathrm{MC}-\mathrm{GOx}$ at different scan rates $\left(20 \mathrm{mV} \mathrm{s}^{-1}\right.$ (a), $50 \mathrm{mV} \mathrm{s}^{-1}$ (b), $70 \mathrm{mV} \mathrm{s}^{-1}$ (c), $100 \mathrm{mV} \mathrm{s}^{-1}$ (d), $200 \mathrm{mV} \mathrm{s}^{-1}$ (e)), insets $\left(B_{1}\right.$ and $B_{2}$ ) are plots of anodic and cathodic peak currents vs. scan rate and peak potentials vs. log scan rates respectively.

\section{Discussion}

\subsection{Effect of Oxidation Reaction Conditions on the GOx Adsorption}

The results showed that the oxidation temperature and time for $\mathrm{MC}$ functionalization could significantly influence the amount of enzyme immobilized on $\mathrm{MC}-\mathrm{COOH}$. When the oxidative temperature increased from 30 to $60^{\circ} \mathrm{C}$ and the oxidative time increased from $6 \mathrm{~h}$ to $48 \mathrm{~h}$, the ability of the mesoporous carbon to immobilize GOx increased. This enhanced enzyme adsorption might be due to the remarkable binding affinity of the oxygen-containing groups (mainly $\mathrm{COOH}$ groups) on the surface for the functionalized MC [79]. When the oxidation temperature and time further reached a threshold of $60^{\circ} \mathrm{C}$ or $48 \mathrm{~h}$, respectively, a huge number of micropores were damaged or blocked, which led to a reduction in GOx immobilization [36]. Interestingly, when the oxidation temperature and time were further raised to $60^{\circ} \mathrm{C}$ or $48 \mathrm{~h}$, more GOx immobilization was observed in $\mathrm{MC}-\mathrm{COOH}$. A possible explanation was that as the oxidation reaction became harsher, some of the blocked micropores could be opened again and become suitable for enzyme adsorption [36]. Furthermore, for the MC treated with a $2 \mathrm{M}$ APS solution, the amount of GOx adsorbed at $50{ }^{\circ} \mathrm{C}$ is $2.81 \mathrm{mg} / 20 \mathrm{mg}$ MC (Figure $2 \mathrm{~b}$ ), much higher than that of the MC samples treated with other APS concentrations. This result suggested that treatment with a high concentration of APS could introduce more $\mathrm{COOH}$ groups at low temperature.

\subsection{Effect of MC Carboxylation on GOx Immobilization}

Compared to those of the enzyme immobilized on $\mathrm{MC}$, the amount and activity of the enzyme immobilized on MC-COOH increased by $130.47 \%$ and $252.74 \%$, respectively. The reason may be that the carboxylic groups endow $\mathrm{MC}-\mathrm{COOH}$ with hydrophilicity and ionic character, thus facilitating the interactions of immobilization. The basal plane itself was electrochemically inert with no such sites ideally contained. GOx was fixed onto the MC-COOH electrode by covalent coupling to construct the enzymatic glucose electrode. Incubation of GOx solution with the MC-COOH electrode led to sufficient contact between the $\mathrm{COOH}$ groups of $\mathrm{MC}$ and $\mathrm{NH}_{2}$ groups on the GOx surface, giving rise to the amide bond (CO-NH) formation [79]. Besides, the apparent reduction in the BET specific surface area 
and total pore volume of the $\mathrm{MC}-\mathrm{COOH}$ samples compared to the $\mathrm{MC}$ samples was further evidence of the active loading of GOx inside the mesopores because of carboxylation.

\subsection{Improved Characteristics of the Bioelectrode}

The - $\mathrm{COOH}$ groups on the carboxylated mesoporous carbon had no effect on the GOx activity or structure, even though these groups could not only physically adsorb GOx but also covalently couple with GOx, thereby increasing the amount of immobilized enzyme and the GOx surface coverage of the enzyme electrode. The results of cyclic voltammetry of Nafion/MC and Nafion/MC-COOH, as shown in Figure $5(\mathrm{a}, \mathrm{b}, \mathrm{e}, \mathrm{h})$, show no redox processes occurring with the Nafion/MC and Nafion/MC-COOH electrode in the potential range where the redox peaks of GOx are expected to appear. Shown as the $\mathrm{CV}$ curves $\mathrm{c}$ and $\mathrm{d}$ in Figure 5, the oxidation and reduction peak current increased when the amount of GOx immobilization increased on the modified electrode. The redox peak current signal increased probably due to the electron transfer that occurs between the active sites of glucose oxidase and MC or MC-COOH electrodes [47]. Moreover, the GOx immobilized on $\mathrm{MC}-\mathrm{COOH}$ presented higher unit enzyme activity of $406.60 \mathrm{U} \mathrm{mg}^{-1}$, which was 1.65 times greater than that of GOx immobilized on MC. Thus, the enzyme is not denatured or inactivated, and the glucose oxidation by GOx might be the main reason for producing the anodic peak. The scan rate dependence of the peak currents of the Nafion/GOx/MC and Nafion/GOx/MC-COOH electrodes is plotted in Figure 6 inset $\mathrm{A}_{1}, \mathrm{~B}_{1}$. The linear dependence of the peak currents on the scan rate indicates that the redox reaction observed is due to GOx immobilized on the electrode [55]. Thus, it was reasonable to speculate that the enzymatic activity and native conformation had been well retained in the GOx immobilized on MC-COOH [80].

Additionally, the GOx surface coverage of the Nafion/GOx/MC-COOH electrode was calculated to be $22.92 \%$, which was higher than that of the Nafion/GOx/MC electrode. Moreover, this surface coverage was more extensive than that of GOx coated on the surface of a carbon-ceramic electrode (CCE) $\left(1.8 \times 10^{-9} \mathrm{~mol} \mathrm{~cm}^{-2}\right)$ [81], MWCNT/PyBA-GOxGA $\left(3.58 \times 10^{-10} \mathrm{~mol} \mathrm{~cm}^{-2}\right)$ and MWCNT/PyBA-GOxEDC $\left(1.15 \times 10^{-9} \mathrm{~mol} \mathrm{~cm}^{-2}\right)$ [82]. The wide surface area and excellent biocompatibility of MC-COOH and MC increased the absorption of GOx. Therefore, the MC-COOH nanocomposites could provide a beneficial microenvironment for the substantial activity retention and immobilization of GOx. These results demonstrated that the Nafion/GOx/MC-COOH electrode was more advanced for the direct electron transfer of GOx than the Nafion/GOx/MC electrode and some other electrodes [77].

The work of the authors and other references have been compared and shown in the Table 3 . Compared with other bioelectrode and biosensors constructed with GOx, our system presented higher anodic peak current and reduction peak current. Moreover, the GOx surface coverage in our system is more than that of other systems. Results indicated that the carboxylized functionalization could enhance the enzyme coverage and activity of the bioelectrode to improve the peak current.

Table 3. Comparison between various GOx bioelectrodes.

\begin{tabular}{|c|c|c|c|c|c|c|}
\hline Electrode & Substrate & $\begin{array}{l}\text { Anodic } \\
\text { Peak } \\
\text { Current }\end{array}$ & $\begin{array}{c}\text { Reduction } \\
\text { Peak } \\
\text { Current }\end{array}$ & $\begin{array}{c}\text { Quality of } \\
\text { Immobilized } \\
\text { Enzyme } \\
\text { (GOx mg/g) }\end{array}$ & $\begin{array}{c}\text { GOx } \\
\text { Surface } \\
\text { Coverage }\end{array}$ & References \\
\hline Nafion/GOx/MC-COOH & $\mathrm{C}_{6} \mathrm{H}_{12} \mathrm{O}_{6}$ & $\begin{array}{l}15.66 \mathrm{~mA} \\
(50 \mathrm{mv} / \mathrm{s})\end{array}$ & $2.39 \mathrm{~mA}$ & 140.72 & $\begin{array}{c}1.29 \times 10^{-8} \\
\mathrm{~mol} \mathrm{~cm}^{-2}\end{array}$ & This study \\
\hline GC/CB/GOx & $\mathrm{C}_{6} \mathrm{H}_{12} \mathrm{O}_{6}$ & $0.045 \mathrm{~mA}$ & $0.036 \mathrm{~mA}$ & 42 & & [52] \\
\hline RGO-AuNPs/PNR/GOx & $\mathrm{C}_{6} \mathrm{H}_{12} \mathrm{O}_{6}$ & $0.012 \mathrm{~mA}$ & $0.006 \mathrm{~mA}$ & & $\begin{array}{c}3.06 \times 10^{-11} \\
\mathrm{~mol} \mathrm{~cm}^{-2}\end{array}$ & [72] \\
\hline GOD/PGR $2 / G C E$ & $\mathrm{C}_{6} \mathrm{H}_{12} \mathrm{O}_{6}$ & $0.009 \mathrm{~mA}$ & $0.007 \mathrm{~mA}$ & & $\begin{array}{c}2.3 \times 10^{-10} \\
\mathrm{~mol} \mathrm{~cm}^{-2}\end{array}$ & [73] \\
\hline $\mathrm{CPE} / \mathrm{GOx}-\mathrm{SiO}_{2} / \mathrm{Lig} / \mathrm{FC}$ & $\mathrm{C}_{6} \mathrm{H}_{12} \mathrm{O}_{6}$ & $1.10 \mathrm{~mA}$ & $1.25 \mathrm{~mA}$ & 25.28 & & [67] \\
\hline
\end{tabular}




\section{Conclusions}

Electrodes constructed by the immobilization of GOx on MC-COOH exhibited good electrochemical performance. Carboxylated MC was prepared using APS as the oxidant. During this process, oxygen surface groups could be generated, with the pore volume and specific surface area well-maintained. According to single-factor experiments, the conditions of $50{ }^{\circ} \mathrm{C}$, a $2 \mathrm{M}$ APS concentration and $24 \mathrm{~h}$ were chosen for the carboxyl addition. Electrochemical characteristics analysis showed that Nafion/GOx/MC-COOH presented better electrocatalytic activity with enhancing peak current intensity (up to 1.13-fold), increasing reduction peak current of $\mathrm{O}_{2}$ (up to 4.98 times), rising anodic charge-transfer coefficients ( $\alpha$ ) (from 0.67 to 0.77 ), compared to Nafion/GOx/MC. Results showed that carboxylation is a promising strategy for improving the bio-electrode performance through favoring the active catalyst surface and current intensity.

Author Contributions: Conceptualization, C.L. and X.Y.; Data curation, C.L.; Formal analysis, C.L.; Funding acquisition, S.L. and X.Y.; Investigation, C.L. and L.L.; Methodology, C.L. and X.Y.; Project administration, S.L. and X.Y.; Resources, C.L., L.L. and X.Z.; Software, C.L., L.L. and X.Z.; Supervision, S.L. and X.Y.; Validation, C.L.; Visualization, X.Y.; Writing-original draft, C.L.; Writing-review and editing, S.L. and X.Y. All authors have read and agreed to the published version of the manuscript.

Funding: This research was funded by National Science Foundation of Guangdong Province, grant number 2018A030313139; the Development of Special Funds for Shenzhen Strategic Emerging Industries and Future Industries, grant number KJYY20180201180253571; the Shenzhen Science and Technology Innovation Shenzhen-Hong Kong Joint Research Project, grant number SGLH2O180622152010394; and the Shenzhen Overseas High-level Talent Innovation and Entrepreneurship Fund Project, grant number KQJSCX20180328093806045.

Conflicts of Interest: The authors declare no conflict of interest.

\section{References}

1. Du Toit, H.; Di Lorenzo, M. Glucose Oxidase Directly Immobilized onto Highly Porous Gold Electrodes for Sensing and Fuel Cell Applications. Electrochim. Acta 2014, 138, 86-92. [CrossRef]

2. Chen, Y.; Gai, P.; Zhang, J.; Zhu, J.-J. Design of an Enzymatic Biofuel Cell with Large Power Output. J. Mater. Chem. A 2015, 3, 11511-11516. [CrossRef]

3. Karimi, A.; Othman, A.; Uzunoglu, A.; Stanciu, L.; Andreescu, S. Graphene Based Enzymatic Bioelectrodes and Biofuel Cells. Nanoscale 2015, 7, 6909-6923. [CrossRef] [PubMed]

4. Holzinger, M.; Le Goff, A.; Cosnier, S. Carbon Nanotube/Enzyme Biofuel Cells. Electrochim. Acta 2012, 82, 179-190. [CrossRef]

5. Yang, J.; Hu, D.; Zhang, X.; Wang, K.; Wang, B.; Sun, B.; Qiu, Z. Enzyme-Catalyzed Biocathode in a Photoelectrochemical Biofuel Cell. J. Power Sources 2014, 267, 617-621. [CrossRef]

6. Cosnier, S.; Le Goff, A.; Holzinger, M. Towards Glucose Biofuel Cells Implanted in Human Body for Powering Artificial Organs: Review. Electrochem. Commun. 2014, 38, 19-23. [CrossRef]

7. Cooney, M.; Svoboda, V.; Lau, C.; Martin, G.; Minteer, S. Enzyme Catalysed Biofuel Cells. Energy Environ. Sci. 2008, 1, 320-337. [CrossRef]

8. Ndamanisha, J.C.; Guo, L.-P. Ordered Mesoporous Carbon for Electrochemical Sensing: A Review. Anal. Chim. Acta 2012, 747, 19-28. [CrossRef]

9. Wu, P.; Shao, Q.; Hu, Y.; Jin, J.; Yin, Y.; Zhang, H.; Cai, C. Direct Electrochemistry of Glucose Oxidase Assembled on Graphene and Application to Glucose Detection. Electrochim. Acta 2010, 55, 8606-8614. [CrossRef]

10. Yu, J.; Yu, D.; Zhao, T.; Zeng, B. Development of Amperometric Glucose Biosensor through Immobilizing Enzyme in a Pt Nanoparticles/Mesoporous Carbon Matrix. Talanta 2008, 74, 1586-1591. [CrossRef]

11. Rasmussen, M.; Abdellaoui, S.; Minteer, S.D. Enzymatic Biofuel Cells: 30 Years of Critical Advancements. Biosens. Bioelectron. 2016, 76, 91-102. [CrossRef] [PubMed]

12. Kim, J.; Grate, J.W.; Wang, P. Nanobiocatalysis and Its Potential Applications. Trends Biotechnol. 2008, 26, 639-646. [CrossRef] [PubMed]

13. Liu, C.; Alwarappan, S.; Chen, Z.; Kong, X.; Li, C.-Z. Membraneless Enzymatic Biofuel Cells Based on Graphene Nanosheets. Biosens. Bioelectron. 2010, 25, 1829-1833. [CrossRef] [PubMed] 
14. Ravenna, Y.; Xia, L.; Gun, J.; Mikhaylov, A.A.; Medvedev, A.G.; Lev, O.; Alfonta, L. Biocomposite Based on Reduced Graphene Oxide Film Modified with Phenothiazone and Flavin Adenine Dinucleotide-Dependent Glucose Dehydrogenase for Glucose Sensing and Biofuel Cell Applications. Anal. Chem. 2015, 87, 9567-9571. [CrossRef] [PubMed]

15. Yan, Y.-M.; Yehezkeli, O.; Willner, I. Integrated, Electrically Contacted Nad(P)+-Dependent Enzyme-Carbon Nanotube Electrodes for Biosensors and Biofuel Cell Applications. Chem. Eur. J. 2007, 13, 10168-10175. [CrossRef] [PubMed]

16. Kwon, C.H.; Lee, S.-H.; Choi, Y.-B.; Lee, J.A.; Kim, S.H.; Kim, H.-H.; Spinks, G.M.; Wallace, G.G.; Lima, M.D.; Kozlov, M.E.; et al. High-Power Biofuel Cell Textiles from Woven Biscrolled Carbon Nanotube Yarns. Nat. Commun. 2014, 5, 3928. [CrossRef]

17. Li, X.; Zhou, H.; Yu, P.; Su, L.; Ohsaka, T.; Mao, L. A Miniature Glucose/O2 Biofuel Cell with Single-Walled Carbon Nanotubes-Modified Carbon Fiber Microelectrodes as the Substrate. Electrochem. Commun. 2008, 10, 851-854. [CrossRef]

18. Guo, C.X.; Hu, F.P.; Lou, X.W.; Li, C.M. High-Performance Biofuel Cell Made with Hydrophilic Ordered Mesoporous Carbon as Electrode Material. J. Power Sources 2010, 195, 4090-4097. [CrossRef]

19. Trifonov, A.; Herkendell, K.; Tel-Vered, R.; Yehezkeli, O.; Woerner, M.; Willner, I. Enzyme-Capped Relay-Functionalized Mesoporous Carbon Nanoparticles: Effective Bioelectrocatalytic Matrices for Sensing and Biofuel Cell Applications. ACS Nano 2013, 7, 11358-11368. [CrossRef]

20. Walcarius, A. Recent Trends on Electrochemical Sensors Based on Ordered Mesoporous Carbon. Sensors 2017, 17, 8. [CrossRef]

21. Walcarius, A. Mesoporous Materials-Based Electrochemical Sensors. Electroanalysis 2015, 27, $1303-1340$. [CrossRef]

22. Catalano, P.N.; Wolosiuk, A.; Soler-Illia, G.J.A.A.; Bellino, M.G. Wired Enzymes In Mesoporous Materials: A Benchmark for Fabricating Biofuel Cells. Bioelectrochemistry 2015, 106, 14-21. [CrossRef]

23. Wang, H.; Qi, B.; Lu, B.; Bo, X.; Guo, L. Comparative Study on the Electrocatalytic Activities of Ordered Mesoporous Carbons and Graphene. Electrochim. Acta 2011, 56, 3042-3048. [CrossRef]

24. Jia, N.; Wang, Z.; Yang, G.; Shen, H.; Zhu, L. Electrochemical Properties of Ordered Mesoporous Carbon and Its Electroanalytical Application for Selective Determination of Dopamine. Electrochem. Commun. 2007, 9, 233-238. [CrossRef]

25. Liang, C.; Li, Z.; Dai, S. Mesoporous Carbon Materials: Synthesis and Modification. Angew. Chem. Int. Ed. 2008, 47, 3696-3717. [CrossRef] [PubMed]

26. Titirici, M.-M.; Thomas, A.; Antonietti, M. Aminated Hydrophilic Ordered Mesoporous Carbons. J. Mater. Chem. 2007, 17, 3412-3418. [CrossRef]

27. Zhu, C.; Yang, G.; Li, H.; Du, D.; Lin, Y. Electrochemical Sensors and Biosensors Based on Nanomaterials and Nanostructures. Anal. Chem. 2015, 87, 230-249. [CrossRef]

28. Shin, Y.; Fryxell, G.E.; Um, W.; Parker, K.; Mattigod, S.V.; Skaggs, R. Sulfur-Functionalized Mesoporous Carbon. Adv. Funct. Mater. 2007, 17, 2897-2901. [CrossRef]

29. Yang, G.; Tang, L.; Zeng, G.; Cai, Y.; Tang, J.; Pang, Y.; Zhou, Y.; Liu, Y.; Wang, J.; Zhang, S.; et al. Simultaneous Removal of Lead and Phenol Contamination from Water by Nitrogen-Functionalized Magnetic Ordered Mesoporous Carbon. Chem. Eng. J. 2015, 259, 854-864. [CrossRef]

30. Vinu, A.; Hossian, K.Z.; Srinivasu, P.; Miyahara, M.; Anandan, S.; Gokulakrishnan, N.; Mori, T.; Ariga, K.; Balasubramanian, V.V. Carboxy-Mesoporous Carbon and Its Excellent Adsorption Capability for Proteins. J. Mater. Chem. 2007, 17, 1819-1825. [CrossRef]

31. Chi, Y.; Geng, W.; Zhao, L.; Yan, X.; Yuan, Q.; Li, N.; Li, X. Comprehensive Study of Mesoporous Carbon Functionalized with Carboxylate Groups and Magnetic Nanoparticles as a Promising Adsorbent. J. Colloid Interface Sci. 2012, 369, 366-372. [CrossRef] [PubMed]

32. He, J.; Ma, K.; Jin, J.; Dong, Z.; Wang, J.; Li, R. Preparation and Characterization of Octyl-Modified Ordered Mesoporous Carbon Cmk-3 for Phenol Adsorption. Microporous Mesoporous Mater. 2009, 121, 173-177. [CrossRef]

33. Li, J.; Wang, Y.-B.; Qiu, J.-D.; Sun, D.-C.; Xia, X.-H. Biocomposites of Covalently Linked Glucose Oxidase on Carbon Nanotubes for Glucose Biosensor. Anal. Bioanal. Chem. 2005, 383, 918-922. [CrossRef] [PubMed]

34. Mangun, C.L.; Benak, K.R.; Daley, M.A.; Economy, J. Oxidation of Activated Carbon Fibers: Effect on Pore Size, Surface Chemistry, and Adsorption Properties. Chem. Mater. 1999, 11, 3476-3483. [CrossRef] 
35. Li, N.; Ma, X.; Zha, Q.; Kim, K.; Chen, Y.; Song, C. Maximizing the Number of Oxygen-Containing Functional Groups on Activated Carbon by Using Ammonium Persulfate and Improving the Temperature-Programmed Desorption Characterization of Carbon Surface Chemistry. Carbon 2011, 49, 5002-5013. [CrossRef]

36. Wu, Z.; Webley, P.A.; Zhao, D. Comprehensive Study of Pore Evolution, Mesostructural Stability, and Simultaneous Surface Functionalization of Ordered Mesoporous Carbon (Fdu-15) by Wet Oxidation as a Promising Adsorbent. Langmuir 2010, 26, 10277-10286. [CrossRef] [PubMed]

37. Moreno-Castilla, C.; Carrasco-Marín, F.; Mueden, A. the Creation of Acid Carbon Surfaces by Treatment with $\left(\mathrm{Nh}_{4}\right)_{2} \mathrm{~S}_{2} \mathrm{O}_{8}$. Carbon 1997, 35, 1619-1626. [CrossRef]

38. Simaioforidou, A.; Kostas, V.; Karakassides, M.A.; Louloudi, M. Surface Chemical Modification of Macroporous and Mesoporous Carbon Materials: Effect on their Textural and Catalytic Properties. Microporous Mesoporous Mater. 2019, 279, 334-344. [CrossRef]

39. Deb Nath, N.C.; Jeon, I.-Y.; Ju, M.J.; Ansari, S.A.; Baek, J.-B.; Lee, J.-J. Edge-Carboxylated Graphene Nanoplatelets as Efficient Electrode Materials for Electrochemical Supercapacitors. Carbon 2019, 142, 89-98. [CrossRef]

40. Tang, L.; Zhang, S.; Zeng, G.-M.; Zhang, Y.; Yang, G.-D.; Chen, J.; Wang, J.-J.; Wang, J.-J.; Zhou, Y.-Y.; Deng, Y.-C. Rapid Adsorption of 2,4-Dichlorophenoxyacetic Acid by Iron Oxide Nanoparticles-Doped Carboxylic Ordered Mesoporous Carbon. J. Colloid Interface Sci. 2015, 445, 1-8. [CrossRef]

41. Bazuła, P.A.; Lu, A.-H.; Nitz, J.-J.; Schüth, F. Surface and Pore Structure Modification of Ordered Mesoporous Carbons via a Chemical Oxidation Approach. Microporous Mesoporous Mater. 2008, 108, 266-275. [CrossRef]

42. Zheng, N.; Sun, W.; Liu, H.-Y.; Huang, Y.; Gao, J.; Mai, Y.-W. Effects of Carboxylated Carbon Nanotubes on the Phase Separation Behaviour and Fracture-Mechanical Properties of an Epoxy/Polysulfone Blend. Compos. Sci. Technol. 2018, 159, 180-188. [CrossRef]

43. Bo, X.; Ndamanisha, J.C.; Bai, J.; Guo, L. Nonenzymatic Amperometric Sensor of Hydrogen Peroxide and Glucose Based on Pt Nanoparticles/Ordered Mesoporous Carbon Nanocomposite. Talanta 2010, 82, 85-91. [CrossRef] [PubMed]

44. Khan, M.Y.; Khan, A.; Adewole, J.K.; Naim, M.; Basha, S.I.; Aziz, M.A. Biomass Derived Carboxylated Carbon Nanosheets Blended Polyetherimide Membranes for Enhanced Co2/Ch4 Separation. J. Nat. Gas Sci. Eng. 2020, 75, 103156. [CrossRef]

45. Eba, H.; Kitakubo, Y.; Awaji, S.; Takahashi, M. Observation of Crystalline Phase Distribution with Confocal Angle-Dispersive X-Ray Diffractometer. Nucl. Instrum. Methods Phys. Res. Sect. B Beam Interact. Mater. At. 2019, 456, 42-48. [CrossRef]

46. Sierra, U.; Mercado, A.; Cuara, E.; Barriga-Castro, E.D.; Cortés, A.; Gallardo-Vega, C.; Fernández, S. Coke-Derived Few Layer Graphene-Like Materials by Mild Planetary Milling Exfoliation. Fuel 2020, 262, 116455. [CrossRef]

47. Jo, Y.; Cheon, J.Y.; Yu, J.; Jeong, H.Y.; Han, C.-H.; Jun, Y.; Joo, S.H. Highly Interconnected Ordered Mesoporous Carbon-Carbon Nanotube Nanocomposites: Pt-Free, Highly Efficient, and Durable Counter Electrodes for Dye-Sensitized Solar Cells. Chem. Commun. 2012, 48, 8057-8059. [CrossRef]

48. Pazoki, H.; Anbia, M. Synthesis of a Microporous Copper Carboxylate Metal Organic Framework as a New High Capacity Methane Adsorbent. Polyhedron 2019, 171, 108-111. [CrossRef]

49. Chiang, Y.-C.; Chiang, P.-C.; Huang, C.-P. Effects of Pore Structure and Temperature on Voc Adsorption on Activated Carbon. Carbon 2001, 39, 523-534. [CrossRef]

50. Williams, P.T.; Reed, A.R. Development of Activated Carbon Pore Structure via Physical and Chemical Activation of Biomass Fibre Waste. Biomass Bioenergy 2006, 30, 144-152. [CrossRef]

51. Wang, H.; Zhu, H.; Li, Y.; Qi, D.; Wang, S.; Shen, K. Hierarchical Porous Carbon Derived from Carboxylated Coal-Tar Pitch for Electrical Double-Layer Capacitors. RSC Adv. 2019, 9, 29131-29140. [CrossRef]

52. Ania, C.O.; Gomis-Berenguer, A.; Dentzer, J.; Vix-Guterl, C. Nanoconfinement of Glucose Oxidase on Mesoporous Carbon Electrodes with Tunable Pore Sizes. J. Electroanal. Chem. 2018, 808, 372-379. [CrossRef]

53. Wang, K.; Yang, H.; Zhu, L.; Ma, Z.; Xing, S.; Lv, Q.; Liao, J.; Liu, C.; Xing, W. Direct Electron Transfer and Electrocatalysis of Glucose Oxidase Immobilized on Glassy Carbon Electrode Modified with Nafion and Mesoporous Carbon Fdu-15. Electrochim. Acta 2009, 54, 4626-4630. [CrossRef]

54. Kong, F.-Y.; Gu, S.-X.; Li, W.-W.; Chen, T.-T.; Xu, Q.; Wang, W. A Paper Disk Equipped with Graphene/Polyaniline/Au Nanoparticles/Glucose Oxidase Biocomposite Modified Screen-Printed Electrode: Toward Whole Blood Glucose Determination. Biosens. Bioelectron. 2014, 56, 77-82. [CrossRef] 
55. Cui, M.; Xu, B.; Hu, C.; Shao, H.B.; Qu, L. Direct Electrochemistry and Electrocatalysis of Glucose Oxidase on Three-Dimensional Interpenetrating, Porous Graphene Modified Electrode. Electrochim. Acta 2013, 98, 48-53. [CrossRef]

56. Hui, J.; Cui, J.; Xu, G.; Adeloju, S.B.; Wu, Y. Direct Electrochemistry of Glucose Oxidase Based on Nafion-Graphene-God Modified Gold Electrode and Application To Glucose Detection. Mater. Lett. 2013, 108, 88-91. [CrossRef]

57. Bagyalakshmi, S.; Sivakami, A.; Balamurugan, K.S. A Zno Nanorods Based Enzymatic Glucose Biosensor by Immobilization of Glucose Oxidase on a Chitosan Film. Obes. Med. 2020, 18, 100229. [CrossRef]

58. Liu, Q.; Lu, X.; Li, J.; Yao, X.; Li, J. Direct Electrochemistry of Glucose Oxidase and Electrochemical Biosensing of Glucose on Quantum Dots/Carbon Nanotubes Electrodes. Biosens. Bioelectron. 2007, 22, 3203-3209. [CrossRef]

59. Liu, Y.; Wang, M.; Zhao, F.; Xu, Z.; Dong, S. the Direct Electron Transfer of Glucose Oxidase and Glucose Biosensor Based on Carbon Nanotubes/Chitosan Matrix. Biosens. Bioelectron. 2005, 21, 984-988. [CrossRef]

60. Fu, C.; Yang, W.; Chen, X.; Evans, D.G. Direct Electrochemistry of Glucose Oxidase on A Graphite Nanosheet-Nafion Composite Film Modified Electrode. Electrochem. Commun. 2009, 11, 997-1000. [CrossRef]

61. Xu, Q.; Gu, S.-X.; Jin, L.; Zhou, Y.-E.; Yang, Z.; Wang, W.; Hu, X. Graphene/Polyaniline/Gold Nanoparticles Nanocomposite for the Direct Electron Transfer of Glucose Oxidase and Glucose Biosensing. Sens. Actuators B Chem. 2014, 190, 562-569. [CrossRef]

62. Garcia-Perez, T.; Hong, S.-G.; Kim, J.; Ha, S. Entrapping Cross-Linked Glucose Oxidase Aggregates within A Graphitized Mesoporous Carbon Network for Enzymatic Biofuel Cells. Enzym. Microb. Technol. 2016, 90, 26-34. [CrossRef] [PubMed]

63. Barathi, P.; Thirumalraj, B.; Chen, S.-M.; Angaiah, S. A Simple and Flexible Enzymatic Glucose Biosensor Using Chitosan Entrapped Mesoporous Carbon Nanocomposite. Microchem. J. 2019, 147, 848-856. [CrossRef]

64. Deng, S.; Jian, G.; Lei, J.; Hu, Z.; Ju, H. A Glucose Biosensor Based on Direct Electrochemistry of Glucose Oxidase Immobilized on Nitrogen-Doped Carbon Nanotubes. Biosens. Bioelectron. 2009, 25, 373-377. [CrossRef] [PubMed]

65. Chang, Y.H.; Woi, P.M.; Alias, Y. the Selective Electrochemical Detection of Dopamine in the Presence of ascorbic Acid and Uric Acid Using Electro-Polymerised-B-Cyclodextrin Incorporated F-Mwcnts/Polyaniline Modified Glassy Carbon Electrode. Microchem. J. 2019, 148, 322-330. [CrossRef]

66. Rębiś, T.; Sobczak, A.; Wierzchowski, M.; Frankiewicz, A.; Teżyk, A.; Milczarek, G. An Approach for Electrochemical Functionalization of Carbon Nanotubes/1-Amino-9,10-Anthraquinone Electrode with Catechol Derivatives for the Development of Nadh Sensors. Electrochim. Acta 2018, 260, 703-715. [CrossRef]

67. Jędrzak, A.; Rębiś, T.; Klapiszewski, Ł.; Zdarta, J.; Milczarek, G.; Jesionowski, T. Carbon Paste Electrode Based on Functional Gox/Silica-Lignin System To Prepare an Amperometric Glucose Biosensor. Sens. Actuators B Chem. 2018, 256, 176-185. [CrossRef]

68. Mani, V.; Devadas, B.; Chen, S.-M. Direct Electrochemistry of Glucose Oxidase at Electrochemically Reduced Graphene Oxide-Multiwalled Carbon Nanotubes Hybrid Material Modified Electrode for Glucose Biosensor. Biosens. Bioelectron. 2013, 41, 309-315. [CrossRef]

69. Xu, X.; Guo, M.; Lu, P.; Wang, R. Development of Amperometric Laccase Biosensor Through Immobilizing Enzyme in Copper-Containing Ordered Mesoporous Carbon (Cu-Omc)/Chitosan Matrix. Mater. Sci. Eng. C 2010, 30, 722-729. [CrossRef]

70. Jiang, K.; Zhang, X.; Huang, J.; Wang, S.; Chen, J. Porous Hollow Tubular Carbon Materials Based on Zeolitic Imidazolate Framework-8 Derived from Zno Nanorods as New Enzyme Immobilizing Matrix for High-Performance Bioanode of Glucose/O2 Biofuel Cells. J. Electroanal. Chem. 2017, 796, 88-95. [CrossRef]

71. Baker, R.; Wilkinson, D.P.; Zhang, J. Electrocatalytic Activity and Stability of Substituted Iron Phthalocyanines towards Oxygen Reduction Evaluated at Different Temperatures. Electrochim. Acta 2008, 53, 6906-6919. [CrossRef]

72. Mazar, F.M.; Alijanianzadeh, M.; Molaeirad, A.; Heydari, P. Development of Novel Glucose Oxidase Immobilization on Graphene/Gold Nanoparticles/Poly Neutral Red Modified Electrode. Process. Biochem. 2017, 56, 71-80. [CrossRef]

73. Gonçales, V.R.; Colombo, R.N.P.; Minadeo, M.A.O.S.; Matsubara, E.Y.; Rosolen, J.M.; Córdoba De Torresi, S.I. Three-Dimensional Graphene/Carbon Nanotubes Hybrid Composites for Exploring Interaction Between Glucose Oxidase and Carbon Based Electrodes. J. Electroanal. Chem. 2016, 775, 235-242. [CrossRef] 
74. Zuo, S.; Teng, Y.; Yuan, H.; Lan, M. Direct Electrochemistry of Glucose Oxidase on Screen-Printed Electrodes Through one-Step Enzyme Immobilization Process with Silica Sol-Gel/Polyvinyl Alcohol Hybrid Film. Sens. Actuators B Chem. 2008, 133, 555-560. [CrossRef]

75. Laviron, E. General Expression of the Linear Potential Sweep Voltammogram In the Case of Diffusionless Electrochemical Systems. J. Electroanal. Chem. Interfacial Electrochem. 1979, 101, 19-28. [CrossRef]

76. Hess, A.; Roode-Gutzmer, Q.; Heubner, C.; Schneider, M.; Michaelis, A.; Bobeth, M.; Cuniberti, G. Determination of State of Charge-Dependent Asymmetric Butler-Volmer Kinetics for $\mathrm{Li}_{\mathrm{x}} \mathrm{COO}_{2}$ Electrode Using Gitt Measurements. J. Power Sources 2015, 299, 156-161. [CrossRef]

77. Wang, L.; Bai, J.; Bo, X.; Zhang, X.; Guo, L. A Novel Glucose Sensor Based on Ordered Mesoporous Carbon-Au Nanoparticles Nanocomposites. Talanta 2011, 83, 1386-1391. [CrossRef]

78. Jin-Zhong, X.; Jun-Jie, Z.; Qiang, W.; Zheng, H.; Hong-Yuan, C. Direct Electron Transfer Between Glucose Oxidase and Multi-Walled Carbon Nanotubes. Chin. J. Chem. 2003, 21, 1088-1091. [CrossRef]

79. Lata, S.; Batra, B.; Karwasra, N.; Pundir, C.S. an Amperometric $\mathrm{H}_{2} \mathrm{O}_{2}$ Biosensor Based on Cytochrome C Immobilized onto Nickel Oxide Nanoparticles/Carboxylated Multiwalled Carbon Nanotubes/Polyaniline Modified Gold Electrode. Process Biochem. 2012, 47, 992-998. [CrossRef]

80. Wang, G.; Thai, N.M.; Yau, S.-T. Preserved Enzymatic Activity of Glucose Oxidase Immobilized on an Unmodified Electrode. Electrochem. Commun. 2006, 8, 987-992. [CrossRef]

81. Razmi, H.; Mohammad-Rezaei, R. Graphene Quantum Dots as a New Substrate for Immobilization and Direct Electrochemistry of Glucose Oxidase: Application to Sensitive Glucose Determination. Biosens. Bioelectron. 2013, 41, 498-504. [CrossRef] [PubMed]

82. Kowalewska, B.; Jakubow, K. The Impact of Immobilization Process on the Electrochemical Performance, Bioactivity and Conformation of Glucose Oxidase Enzyme. Sens. Actuators B Chem. 2017, 238, 852-861. [CrossRef]

(C) 2020 by the authors. Licensee MDPI, Basel, Switzerland. This article is an open access article distributed under the terms and conditions of the Creative Commons Attribution (CC BY) license (http://creativecommons.org/licenses/by/4.0/). 